\title{
Recommendation of RILEM TC 258-AAA: RILEM AAR-8: determination of potential releasable alkalis by aggregates in concrete
}

\author{
Esperanza Menéndez $\mathbb{D} \cdot$ António Santos Silva · Josée Duchesne
}

Received: 3 November 2020/ Accepted: 12 March 2021/Published online: 26 October 2021

(C) RILEM 2021

\begin{abstract}
The test method AAR-8 is intended to be used for assessing the potential amount of alkalis released by aggregates in field concrete in the longterm. This is done by measuring the amounts of sodium and potassium ions released from the fine graded $(<4 \mathrm{~mm})$ aggregate immersed in $(0.7 \mathrm{M}) \mathrm{KOH}$ and $\mathrm{NaOH}$ solutions, respectively, at elevated
\end{abstract}

\section{TC Members:}

Chair: Børge Johannes WIGUM.

Deputy Chair: Jan LINDGÅRD.

Members: Mark G. ALEXANDER, Mario BERRA, Ingmar BORCHERS, Maarten BROEKMANS, Rene BRUECKNER, João CUSTÓDIO, Vinh DAO, Mario DE ROOIJ, Klaartje DE WEERDT, Josée DUCHESNE, Rui Miguel FERREIRA, Benoît FOURNIER, Sue FREITAG, Ricardo GARCIAROVES LOZA, Eric GIANNINI, Colin GIEBSON, Michal A. GLINICKI, R. Doug HOOTON, Jason H. IDEKER, Patricija KARA DE MAEIJER, Yuichiro KAWABATA, Stefan KRISPEL, Selmo C. KUPERMAN, Andreas LEEMANN, Lech LEWCZUK, Jan LINDGÅRD, Tung Chai LING, QingFeng LIU, Renaud-Pierre MARTIN, Esperanza MENENDEZ MENDEZ, Birgit MENG, Urs MÜLLER, Christoph MÜLLER, Bård M. PEDERSEN, Gilles PLUSQUELLEC, Terje F. RØNNING, Leandro SANCHEZ, Antonio SANTOS SILVA, Ignacio SEGURA, Katrin SEYFARTH, Gintautas SKRIPKIUNAS, Zhenguo SHI, Ian SIMS, Suvimol SUJJAVANICH, Michael D. A. THOMAS, Børge Johannes WIGUM, Jonathan WOOD, Kazuo YAMADA.

E. Menéndez $(\square)$

El Instituto de Ciencias de la Construcción Eduardo

Torroja (IETcc), c/ Serrano Galvache, no 4,

28033 Madrid, Spain

e-mail: emm@ietcc.csic.es temperature when in contact with excess calcium hydroxide. It is of great importance to realise that this accelerated test method must be considered as a mere indication of potential (maximum) alkali release by the aggregates, rather than a quantification used for the alkali inventory calculations.

Keywords Alkalis release $\cdot$ Aggregates $\cdot$ Test method

\section{Foreword}

This draft method was based on a literature survey on the subject and on the work developed at LCPC (now Université Gustave Eiffel (prev. IFSTTAR), France), Laval Univ. (Quebec City, Canada), Institute Eduardo Torroja IETcc-CSIC (Spain) and LNEC (Portugal) [1-13].
A. S. Silva
Laboratório Nacional de Engenharia Civil (LNEC),
Avenida do Brasil, 101. 1700-066, Lisboa, Portugal
e-mail: ssilva@lnec.pt 


\section{Scope}

This test method is used to assess the potential amount of alkalis released by aggregates in the long-term use in field concrete. This accelerated method must be considered as a mere indication of potential alkali (see Note 1) release by the aggregates rather than a quantification used for the alkali inventory calculation.

Results should be seen as a way to categorize the potential alkali release into three groups: the low, medium and high releasers.

Note 1: in this document, the term alkalis refer to the alkali metal ions $\mathrm{Na}^{+}$and $\mathrm{K}^{+}$.

\section{Significance and use}

Many field and laboratory investigations on concrete, mortar or aggregate samples demonstrated or suggested that some aggregates or mineral phases present within the aggregate particles can supply significant amounts of alkalis to the pore solution over the service life of the concrete. This becomes a source of concern when concrete is exposed to relative humidity over 80 $\%$ and contains potentially AAR aggregates, and when the mitigation for deleterious AAR is arranged by limiting the alkalis from the cement and/or by using specified amounts of supplementary cementing materials.

A number of procedures have been used in the past for assessing the alkali contribution from the aggregates to the pore solution of concrete [14]. Most of these procedures involved immersion of the aggregates in a lime-saturated solution, with or without solid lime in excess, or in alkaline $(\mathrm{NaOH}, \mathrm{KOH})$ solutions. However, there is still no consensus about the absolute amounts that can be released by the aggregates in concrete, the procedure to be used to estimate these amounts, and the way to take account for this alkali contribution in the standards or guidelines. Recently, strategies for quantification of alkali metal release from aggregates into the concrete in field were discussed [15]. AAR-8 provides a mean of

\footnotetext{
J. Duchesne

Université Laval, 2325 rue de l'Université Québec,

Laval, QC G1V 0A6, Canada

e-mail: josee.duchesne@ggl.ulaval.ca
}

evaluating the amount of potential alkalis releasable by aggregates in the long term use in concrete by measuring the amounts of alkali ions released in $\mathrm{NaOH}\left(\mathrm{K}^{+}\right.$release $)$and $\mathrm{KOH}\left(\mathrm{Na}^{+}\right.$release $)$solutions at elevated temperature. The solutions used should be in contact with excess (solid) calcium hydroxide as this is the situation in concrete in practice.

The values obtained by this test method present most likely a significant overestimation compared to the release in field concrete. This overestimation is mainly due to particle size used to accelerate the test method. Fine aggregate is more susceptible to release alkali than coarse aggregate. At this stage, it is only possible to categorize the aggregate according to the amount of alkali release. Low releasers are aggregates that release less than $0.1 \% \mathrm{Na}_{2} \mathrm{O}_{\text {eq }}$ at 26 weeks while high releasers are aggregates that release more than $0.25 \% \mathrm{Na}_{2} \mathrm{O}_{\text {eq }}$ at 26 weeks. For high releasers, extra caution should be taken in the selection of AAR mitigation measures.

\section{Principle}

Representative samples of a dried aggregate intended for use in concrete are immersed in specific volumes of $0.7 \mathrm{M} \mathrm{NaOH}$ or $\mathrm{KOH}$ solutions with excess calcium hydroxide maintained at $38{ }^{\circ} \mathrm{C}$, using a solution-toaggregate ratio of $4 \mathrm{~L} / \mathrm{kg}$. Twice a week, the test containers are agitated for 10 seconds. At 2, 6, 13 and 26 weeks, samples of the immersion test solution are removed by pipetting and chemically analysed for potassium $(\mathrm{NaOH}$ test solution) or sodium $(\mathrm{KOH}$ test solution). The amount of alkalis released are expressed in milligrams of $\mathrm{Na}_{2} \mathrm{O}, \mathrm{K}_{2} \mathrm{O}$ and $\% \mathrm{Na}_{2} \mathrm{O}_{\text {eq }}$ per kilogram of aggregate.

\section{Apparatus}

\subsection{Sieves}

A set of sieves conforming to series A of ISO 6274 [16], having square apertures of $4 \mathrm{~mm}, 2 \mathrm{~mm}, 1 \mathrm{~mm}$, $500 \mu \mathrm{m}, 250 \mu \mathrm{m}$ and $125 \mu \mathrm{m}$. Alternatively, the equivalent sieves of series B $(4.75 \mathrm{~mm}, 2.36 \mathrm{~mm}, 1.18$ $\mathrm{mm}, 600 \mu \mathrm{m}, 300 \mu \mathrm{m}$ and $150 \mu \mathrm{m})$ or C $(5 \mathrm{~mm}, 2.5$ $\mathrm{mm}, 1.25 \mathrm{~mm}, 630 \mu \mathrm{m}, 315 \mu \mathrm{m}$ and $160 \mu \mathrm{m})$ can be used. 


\subsection{Balance}

A balance capable of weighing $500 \mathrm{~g}$ with an accuracy of $1 \mathrm{~g}$.

\subsection{Volumetric flask}

Volumetric flask of 0.5 litres.

\subsection{Pipettes}

$10 \mathrm{~mL}$ capacity pipettes.

\subsection{Containers for aggregate immersion test}

Containers for the aggregate immersion tests shall be cylindrical, non-absorbent, non-abrasive, non-brittle material, and made of plastic or other material resistant to corrosion by solutions of $\mathrm{NaOH}$ and $\mathrm{KOH}$ at a temperature of $38^{\circ} \mathrm{C}$ for the duration of the test. Each container must be of such dimension and shape to accommodate the specified volumes of aggregates $(100 \mathrm{~g})$ and alkaline solutions $(400 \mathrm{~mL})$, and must be provided with a tight screw-lid or other suitable means to prevent any loss of aggregate particles, solution or moisture by leaking or evaporation. The containers for the aggregates must be single use to avoid risk of breakage. An example of a suitable container is shown in the Fig. 1.

Note 2 (dimension and size of containers): It is recommended to use a container that will have a height-to-diameter ratio of at least 1.5 , to make the sampling of the test solution that is above the aggregates sitting at the bottom of the containers easier and safer.

Note 3 (nature of containers): Polyethylene Nalgene $($ type bottles satisfy the above requirements.

\subsection{Oven}

An oven or room of suitable size to accommodate the required number of containers maintained at temperatures of $38 \pm 2{ }^{\circ} \mathrm{C}$.

\subsection{Filtration}

The apparatus for under vacuum filtration of the $10 \mathrm{~mL}$ samples of immersion solutions should include a filter support, filter papers (grade 40), a perforated rubber

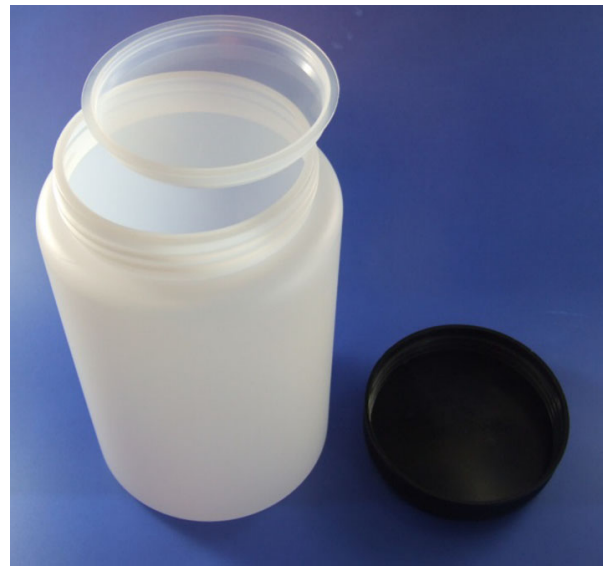

Fig. 1 Example of double-closure container, with $\Phi 10 \mathrm{~cm} \times$ $15 \mathrm{~cm}$ high

plug, a polyethylene Erlenmeyer flask with a connection for air vacuum, and an air-vacuum pump with an appropriate line for connecting to the Erlenmeyer flask (Fig. 2). Another efficient method for filtration could be a syringe filter. A single-use filter cartridge with a pore size between 0.22 and $0.45 \mu \mathrm{m}$ is attached to the end of a syringe. The diameter of the micro-filter is 25 $\mathrm{mm}$. A photo of the syringe with the filter and a detail of the micro-filter are shown in the Fig. 3.

\subsection{Chemical analysis}

Appropriate analytical equipment for determination of potassium and sodium concentrations in the samples

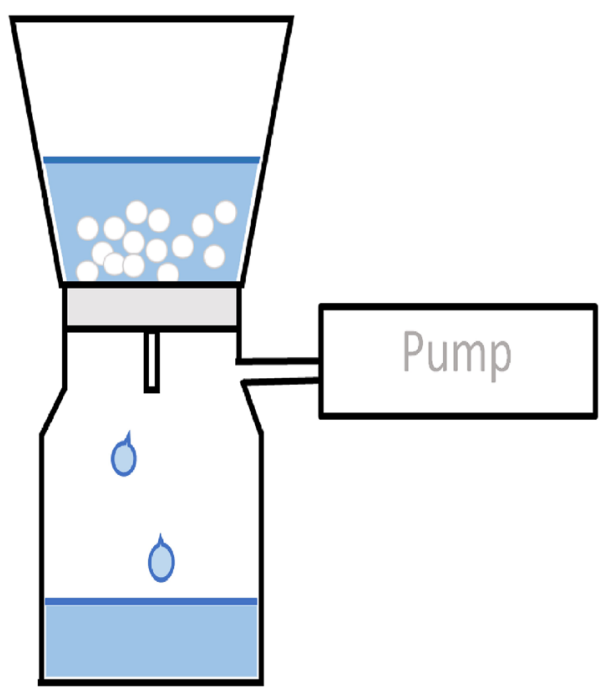

Fig. 2 Diagram of the system of filtration under vacuum 
of immersion solutions included: Atomic Absorption (AAS) and Inductively Couple Plasma Optical Emission Spectroscopy (ICP-OES).

\section{Reagents and materials}

\subsection{Water}

Distilled or de-ionized water.

\subsection{Solid sodium hydroxide}

Reagent grade solid sodium hydroxide with high purity $\geq 95 \%$.

\subsection{Solid potassium hydroxide}

Reagent grade solid potassium hydroxide with high purity $\geq 95 \%$.

\subsection{Sodium hydroxide solution $(\mathrm{NaOH})$ with excess of calcium}

Each litre of sodium hydroxide solution shall contain $28.0 \mathrm{~g}$ of $\mathrm{NaOH}$ and $2.0 \mathrm{~g}$ of $\mathrm{Ca}(\mathrm{OH})_{2}$ dissolved in 900 $\mathrm{mL}$ of water and, after cooling to $20^{\circ} \mathrm{C}$; it shall be diluted with additional distilled water to obtain 1.0 litre of solution. The concentration of the $\mathrm{NaOH}$ in the solution shall be between $0.69 \mathrm{M}$ and $0.71 \mathrm{M}$. A minimum of 1 litre of fresh solution should be prepared for each aggregate to be tested.

Note 4 the concentration of $0.7 \mathrm{M}$ is selected based on the $\mathrm{pH}$ and the corresponding $\mathrm{OH}^{-}$ion concentration of the pore solution of a concrete made with a cement of about $1 \% \mathrm{Na}_{2} \mathrm{Oeq}[17,18]$.

\subsection{Potassium hydroxide solution $(\mathrm{KOH})$ with excess of calcium}

Each litre of potassium hydroxide solution shall contain $39.3 \mathrm{~g}$ of $\mathrm{KOH}$ and $2.0 \mathrm{~g}$ of $\mathrm{Ca}(\mathrm{OH})_{2}$ dissolved in $900 \mathrm{~mL}$ of water and, after cooling to $20^{\circ} \mathrm{C}$, it shall be diluted with additional distilled water to obtain 1.0 litre of solution. The concentration of the $\mathrm{KOH}$ in the solution shall be between 0.69 and $0.71 \mathrm{M}$. A minimum of 1 litre of solution should be prepared for each aggregate.

Note 5 the concentration of $0.7 \mathrm{M}$ is selected based on the $\mathrm{pH}$ and the concentration of ions in the concrete pore solution of a concrete made with a cement of about $1 \% \mathrm{Na}_{2} \mathrm{O}_{\text {eq }}[17,18]$.

\subsection{Nitric acid}

$\mathrm{HNO}_{3}$ concentrated $(65 \%)$.

\section{Procedure}

\subsection{Preparation of the aggregate sample}

The quantity of the sample delivered to the laboratory should be in accordance with the sampling procedures recommended in AAR-1 (Detection of Potential Alkali-Reactivity of Aggregates: Petrographic Method) [19] (see Table 1) or shall represent the composition of the aggregate as proposed for use. The material to be tested shall consist of particles $\leq 4 \mathrm{~mm}$, processed according to 7.1.1 and 7.1.2. With the exception of fraction $<125 \mu \mathrm{m}$, the fractions must be washed over the respective sieve to remove the adhered dust and later dried at $105{ }^{\circ} \mathrm{C}$ before the test (see 7.1.3).
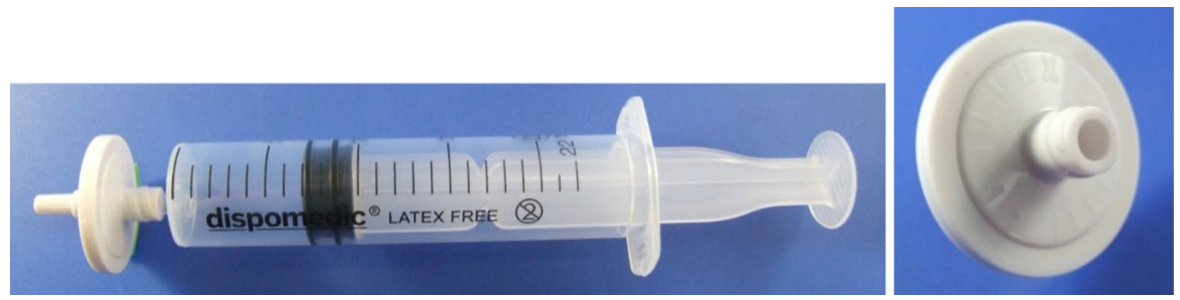

Fig. 3 Example of syringe with the micro-filter and a detail of the filter with diameter $25 \mathrm{~mm}$

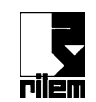


Table 1 Minimum size sample

\begin{tabular}{ll}
\hline Maximum particle size $(\mathrm{mm})$ & Minimum mass $(\mathrm{kg})$ \\
\hline 50 & 200 \\
40 & 100 \\
20 & 15 \\
10 & 5 \\
\hline
\end{tabular}

\subsubsection{Fine aggregate}

The fine aggregate shall be tested in the grading as proposed for use except that particles retained on a 4 $\mathrm{mm}$ sieve, or equivalent (see 5.1), shall be discarded.

\subsubsection{Coarse aggregate}

First, the aggregates sample is sieved with a $4 \mathrm{~mm}$ sieve, this fraction is discarded. Then the remaining material is crush. After crushing by suitable means, the sample must be graded, according to the procedure described in RILEM AAR-2 [20].

\subsubsection{Drying}

The aggregate is tested in an oven-dry condition. A moist aggregate shall be dried at $105 \pm 2{ }^{\circ} \mathrm{C}$ until mass equilibrium (measured at $20 \pm 2{ }^{\circ} \mathrm{C}$ ) before being tested.

\subsection{Preconditioning}

Before testing, the dry aggregate, alkaline solutions and test containers shall be stored at a temperature of $20 \pm 2{ }^{\circ} \mathrm{C}$ for $24 \mathrm{~h} \pm 4 \mathrm{~h}$.

\subsection{Preparation of test mixtures and initial measurements}

\subsubsection{Sample preparation}

Two representative $100 \pm 0.5 \mathrm{~g}$ samples of the aggregate to be tested $\left(\mathrm{M}_{0}\right)$ shall be placed in two test containers (see 5.5). Then $400 \pm 0.1 \mathrm{~mL}$ of the $0.7 \mathrm{M}$ $\mathrm{NaOH}$ solution in excess of $\mathrm{Ca}(\mathrm{OH})_{2}(2.0 \mathrm{~g} / \mathrm{L})$ is added to the first container, while $400 \pm 0.1 \mathrm{~mL}$ of the $0.7 \mathrm{M} \mathrm{KOH}$ solution in excess of $\mathrm{Ca}(\mathrm{OH})_{2}(2.0 \mathrm{~g} / \mathrm{L})$ is added to the second container.

\subsubsection{Blank samples}

Prepare two blank samples by filling one container with $400 \pm 0.1 \mathrm{~mL}$ of the $0.7 \mathrm{M} \mathrm{NaOH}$ solution with excess $\mathrm{Ca}(\mathrm{OH})_{2}(2.0 \mathrm{~g} / \mathrm{L})$, and filling a second container with $400 \pm 0.1 \mathrm{~mL}$ of the $0.7 \mathrm{M} \mathrm{KOH}$ solution with excess $\mathrm{Ca}(\mathrm{OH})_{2}(2.0 \mathrm{~g} / \mathrm{L})$. The blank samples will be stored and periodically sampled together with the aggregate samples.

\subsection{Storage and measurements}

\subsubsection{Storage conditions}

To start the test, the sealed containers are placed in a vertical position in a convection oven or in a water bath maintained at $38 \pm 2{ }^{\circ} \mathrm{C}$, avoiding the loss of humidity by the walls of the containers. Each container must be clearly marked with the aggregate tested and the test solution used. Twice a week during the entire testing program, the containers are removed, one after the other, from the convection oven or water bath and then checked if they are tightly closed and agitated for about 30 seconds, rolling the containers about 20 times through a longitude of 80 centimetres (Fig. 4). The containers are then returned to the convection oven or water bath at $38{ }^{\circ} \mathrm{C}$. The rolling is not necessary for the blank samples.

\subsubsection{Periodic sampling}

Prior to each sampling at the ages of 2, 6, 13 and 26 weeks, the containers are removed from the convection oven or water bath one at a time, agitated for 10 seconds and placed vertically (lid facing up) on a flat surface for $24 \pm 2$ hours in a room at $20^{\circ} \mathrm{C}$, prior to extracting the liquid sample for analysis.

Note 6 during the test, it is possible that there is some agglomeration of the aggregate in the bottom of the container. If the rolling is not sufficient to deagglomerate the aggregate particles it is possible to use a laboratory stirrer or a shaker apparatus to separate the grains.

After this procedure, the container is opened and 10 $\mathrm{mL}$ of solution from each alkaline solution $(0.7 \mathrm{M}$ $\mathrm{NaOH}$ and $\mathrm{KOH}$ solutions) above the aggregate particles is removed by pipetting or using a syringe (see 5.7). From both blank samples without aggregates also $10 \mathrm{~mL}$ is taken for analysis. The solutions are then 

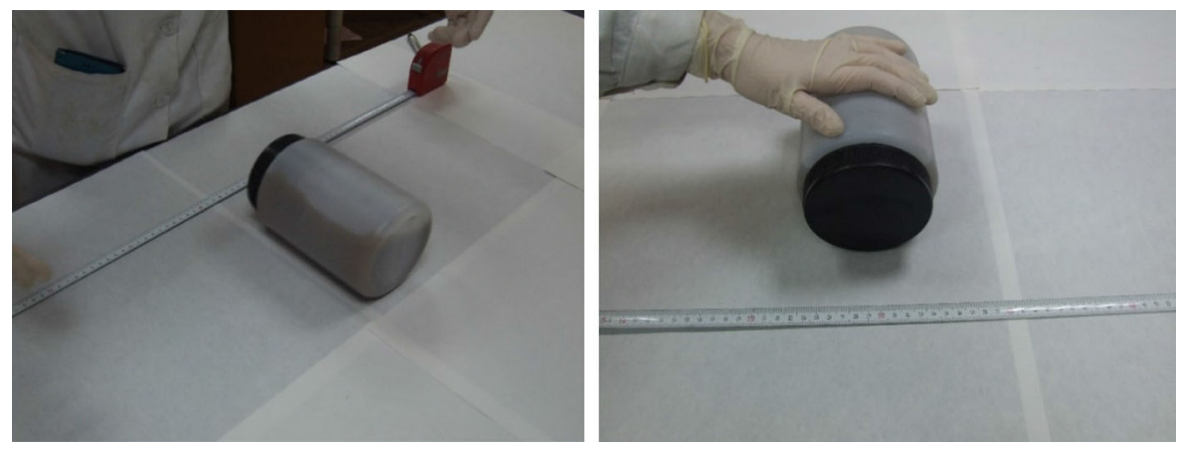

Fig. 4 Rotation of the containers along 80 centimetres on a flat surface

filtered and acidified with $0.25 \mathrm{~mL}$ of $\mathrm{HNO}_{3}$ concentrated and placed in an appropriate closed container to be analysed chemically (see 5.8). If they are not immediately analysed, they can be stored in a refrigerator (between 4 and $10^{\circ} \mathrm{C}$ ) for 2 days maximum until chemical analyses.

After each sampling, the containers are returned to the convection oven or water bath at $38{ }^{\circ} \mathrm{C}$.

\subsubsection{Periodic chemical analysis}

The samples of aggregate immersion solutions and of the corresponding blank solutions taken at each age are chemically analysed for sodium and potassium contents using an appropriate method (see 5.8).

The $\mathrm{Na}^{+}$content must be determined in the $\mathrm{KOH}$ solution and $\mathrm{K}^{+}$content must be measured in the $\mathrm{NaOH}$ solution. Additionally, $\mathrm{K}^{+}$or $\mathrm{Na}^{+}$and $\mathrm{Ca}^{2+}$ can be determined in each solution to obtain more information. Since alkalis are measured in highly charged solutions containing $0.7 \mathrm{M} \mathrm{NaOH}$ or $0.7 \mathrm{M}$ $\mathrm{KOH}$, the matrix has a large effect on the measured concentrations. Special attention should be given to the effect of the matrix. To counteract the matrix effect, it is suggested to prepare the analytical standards with a matrix that represents the samples to be analysed. This implies that the standards must be prepared from $0.7 \mathrm{NaOH}$ and $0.7 \mathrm{KOH}$ stock solutions using the same diluting factors as those used for the samples to be analyzed. For example, the $0 \mathrm{ppm} \mathrm{Na}^{+}$ standard is assigned to the $0.7 \mathrm{M} \mathrm{KOH}$ stock solution diluted and acidified with the same dilution factor as the samples to be analysed. When this technique is used, it is not necessary to subtract the amount of $\mathrm{Na}^{+}$ present in the $\mathrm{KOH}$ solution or the amount of $\mathrm{K}^{+}$in the $\mathrm{NaOH}$ since these quantities are automatically considered by the measurement. The result reported should be the average of at least three analyses.

A discussion of the differences between the analytical test methods (ICP, AAS and others) is given in the paper [21].

Note 7 (continuation of measurements): The sampling could be extended after 26 weeks if is intended to obtain the plateau of alkalis release, being in this case the measurements maintained with periodicity of 3 months.

\subsection{Safety measures}

Reliable safety precautions should be taken, and suitable personal protective equipment should always be used to avoid the hazards of the hot alkaline solution such as severe burns and injuries to unprotected skin and eyes.

\section{Calculation and reporting of results}

\subsection{Alkali concentrations (in $\mathrm{mg} / \mathrm{L}$ )}

The results of the chemical analyses are expressed in milligram of sodium or potassium per litre $\left(\mathrm{mg} \mathrm{K}^{+} / \mathrm{L}\right.$ or $\mathrm{mg} \mathrm{Na}^{+} / \mathrm{L}$ ).

\subsection{Amounts of alkalis released in test solutions (in $\mathrm{mg}$ )}

\subsection{1 $\mathrm{Na}^{+}$released in $\mathrm{KOH}$ solution (in $\mathrm{mg} \mathrm{Na}^{+}$)}

At a given sampling time, the cumulative amount of sodium released in the $\mathrm{KOH}$ solution, in milligrams of $\mathrm{Na}^{+}$, is the amount present in the volume of the test 
solution at the time of sampling, plus the amount present in all $10 \mathrm{~mL}$ samples of the test solution taken before, minus the amount of $\mathrm{Na}^{+}$initially present in the test solution before contact with the aggregate (blank $\mathrm{KOH}$ solution). Accordingly, the cumulative amount of $\mathrm{Na}^{+}$released in the $\mathrm{KOH}$ test solution at the time of the $\mathrm{n}^{\text {th }}$ sampling, in milligrams of $\mathrm{Na}^{+}$, is obtained using the following relationship:

$$
\begin{aligned}
M_{\text {released }}^{\mathrm{Na}=} & {\left[V_{0}^{\mathrm{KOH}}-0.01 \cdot(n-1)\right] \cdot\left(C_{n}^{N a}-C_{0, \mathrm{n}}^{N a}\right) } \\
& +0.01 \cdot \sum_{i=1}^{n-1}\left(C_{i}^{N a}-C_{0, \mathrm{i}}^{N a}\right)
\end{aligned}
$$

where $M_{\text {released }}^{\mathrm{Na}}$, total solid mass of $\mathrm{Na}+$ released from the aggregate $(\mathrm{mg}) . V_{0}^{K O H}$, initial volume of $\mathrm{KOH}$ test solution, in $\mathrm{L}$ (i.e. $0.400 \pm 0.002 \mathrm{~L}$ ). 0.01 , pipetted volume of each solution sampled at the time $\mathrm{t}$, in $\mathrm{L}$ (i.e. $10 \mathrm{~mL}$ ). $n$, total number of the samplings done $(n=1,2,3, \ldots) . C_{n}^{N a}, \mathrm{Na}^{+}$concentration of the KOH test solution with the aggregate at the $n^{\text {th }}$ sampling (mg/L). $C_{0, n}^{N a}, \mathrm{Na}^{+}$concentration in the $\mathrm{KOH}$ blank sample at the nth sampling $(\mathrm{mg} / \mathrm{L}) . C_{i}^{N a}, \mathrm{Na}^{+}$ concentration of the $\mathrm{KOH}$ test solution with the aggregate at the time $t \mathrm{i}$, corresponds to the $i$ th sampling $(\mathrm{mg} / \mathrm{L}) . C_{0, i}^{\mathrm{Na}}, \mathrm{Na}^{+}$concentration in the $\mathrm{KOH}$ blank sample at the $i$ th sampling $(\mathrm{mg} / \mathrm{L})$. iith sampling of the $\mathrm{n}-1$ samplings done $(\mathrm{i}=1,2$, $3, \ldots \mathrm{n}-1$ ). Note 8 (example): As an example, at the time of the 3rd sampling $(n=3)$, i.e. at the age of 13 weeks, the above general relationship corresponds to the following:

$$
\begin{aligned}
M_{\text {released }}^{\mathrm{Na}}= & {\left[V_{0}^{\mathrm{KOH}}-0.01 \cdot(n-1)\right] \cdot\left(C_{n}^{N a}-C_{0, \mathrm{n}}^{N a}\right) } \\
& +0.01 \cdot \sum_{i=1}^{n-1}\left(C_{i}^{N a}-C_{0, \mathrm{i}}^{N a}\right)
\end{aligned}
$$

\subsection{2 $\mathrm{K}^{+}$released in the $\mathrm{NaOH}$ solution (in $\mathrm{mg} \mathrm{K}^{+}$)}

Following the same development as for $\mathrm{Na}^{+}$, the cumulative amount of $\mathrm{K}^{+}$released in the $\mathrm{NaOH}$ test solution at the time of the $\mathrm{n}^{\text {th }}$ sampling, in milligrams of $\mathrm{K}^{+}$, is obtained using the following relationship:

$$
\begin{aligned}
M_{\text {released }}^{K}= & {\left[V_{0}^{\mathrm{NaOH}}-0.01 \cdot(n-1)\right] \cdot\left(C_{n}^{K}-C_{0, \mathrm{n}}^{K}\right) } \\
& +0.01 \cdot \sum_{i=1}^{n-1}\left(C_{i}^{K}-C_{0, \mathrm{i}}^{K}\right)
\end{aligned}
$$

where $M_{\text {released }}^{K}$,total solid mass of $\mathrm{K}+$ released from the aggregate $(\mathrm{mg}) . \mathrm{V}_{0}^{\mathrm{NaOH}}$,initial volume of $\mathrm{NaOH}$ test solution, in L (i.e. $0.400 \pm 0.002$ L). 0.01 ,pipetted volume of each solution sampled at the time $\mathrm{t}$, in $\mathrm{L}$ (i.e. $10 \mathrm{~mL}$ ). $n$, total number of the samplings done $(n=1,2,3, \ldots) . C_{n}^{K}, \mathrm{~K}^{+}$concentration of the $\mathrm{NaOH}$ test solution with the aggregate at the $n$th sampling (mg/L). $C_{0, n}^{K}, \mathrm{~K}^{+}$concentration in the $\mathrm{NaOH}$ blank sample at the $n$th sampling $(\mathrm{mg} / \mathrm{L}) . C_{i}^{K}, \mathrm{~K}^{+}$ concentration of the $\mathrm{NaOH}$ test solution with the aggregate, at the time $t_{i}$, corresponding to the $i$ th sampling (mg/L). $C_{0, i}^{K}, \mathrm{~K}^{+}$concentration in the $\mathrm{NaOH}$ blank sample at the $i$ th sampling $(\mathrm{mg} / \mathrm{L})$. iith sampling of the $n-1$ samplings done $(i=1,2,3, \ldots \mathrm{n}-1)$

\subsection{Amounts of alkali oxides released by the aggregate (in $\mathrm{mg} / \mathrm{kg}$ )}

\subsection{1 $\mathrm{Na}_{2} \mathrm{O}$ released (in $\mathrm{mg} \mathrm{Na}_{2} \mathrm{O} / \mathrm{kg}$ )}

The cumulative amount of $\mathrm{Na}^{+}$released by the aggregate in the $\mathrm{KOH}$ test solution at the time of the $\mathrm{n}^{\text {th }}$ sampling, in milligrams of $\mathrm{Na}_{2} \mathrm{O}$ per kilogram of aggregate, is obtained using the following relationship:

$M_{\text {released }}^{\mathrm{Na}_{2} \mathrm{O}} / \mathrm{kg}=M_{\text {released }}^{\mathrm{Na}}(E q .2) \cdot 1.3480 / M_{0}$

where 1.3480 ,conversion factor to transform a mass of $\mathrm{Na}^{+}$to the equivalent mass of $\mathrm{Na}_{2} \mathrm{O} \cdot M_{O}$, initial mass of aggregate, in $\mathrm{kg}$ (i.e. $0.100 \pm 0.001 \mathrm{~kg}$ )

\subsection{2 $\mathrm{K}_{2} \mathrm{O}$ released (in $\mathrm{mg}_{2} \mathrm{O} / \mathrm{kg}$ )}

The cumulative amount of $\mathrm{K}^{+}$released by the aggregate in the $\mathrm{NaOH}$ test solution at the time of the $\mathrm{n}^{\text {th }}$ sampling, in milligrams of $\mathrm{K}_{2} \mathrm{O}$ per kilogram of aggregate, is obtained using the following relationship:

$$
M_{\text {released }}^{K_{2} O} / k g=M_{\text {released }}^{K}(E q .3) \cdot 1.2046 / M_{0}
$$


where 1.2046,conversion factor to transform a mass of $\mathrm{K}^{+}$to the equivalent mass of $\mathrm{K}_{2} \mathrm{O} . M_{0}$, initial mass of aggregate, in $\mathrm{kg}$ (i.e. $0.100 \pm 0.001 \mathrm{~kg}$ )

\subsection{3 $\mathrm{Na}_{2} \mathrm{Oeq}$ released (in $\mathrm{mg} \mathrm{Na}_{2} \mathrm{Oeq} / \mathrm{kg}$ )}

The cumulative amount of alkalis released by the aggregate in the $\mathrm{NaOH}$ and $\mathrm{KOH}$ test solutions at the time of the $\mathrm{n}^{\text {th }}$ sampling, in milligrams of $\mathrm{Na}_{2} \mathrm{O}_{\text {eq }}$ per kilogram of aggregate, is obtained using the following relationship:

$$
\begin{aligned}
M_{\text {released }}^{\mathrm{Na}_{2} \mathrm{O}_{e q}} / \mathrm{kg}= & M_{\text {released }}^{\mathrm{Na} \mathrm{O}} / \mathrm{kg}(E q .4) \\
& +\left[0.658 \times M_{\text {released }}^{\mathrm{K}_{2} \mathrm{O}} / \mathrm{kg}(E q .5)\right]
\end{aligned}
$$

where 0.658 ,conversion factor to transform a mass of $\mathrm{K}_{2} \mathrm{O}$ to the equivalent atomic mass of $\mathrm{Na}_{2} \mathrm{O}$

\subsection{Amounts of alkali oxides released} by the aggregate (in $\% \mathrm{Na}_{2} \mathrm{O}_{\text {eq }}$ )

\subsection{1 $\mathrm{Na}_{2} \mathrm{O}$ released (in $\% \mathrm{Na}_{2} \mathrm{O}$ )}

The cumulative amount of $\mathrm{Na}^{+}$released by the aggregate in the $\mathrm{KOH}$ test solution at the time of the $\mathrm{n}^{\text {th }}$ sampling, in $\%$ of $\mathrm{Na}_{2} \mathrm{O}$, is obtained using the following relationship:

$\%_{\text {released }}^{\mathrm{Na}_{2} \mathrm{O}}=\left[\mathrm{M}_{\text {released }}^{\mathrm{Na}_{2} \mathrm{O}} / \mathrm{kg}\right] / 10^{6} \times 100$

where $10^{6}$, conversion factor between $\mathrm{kg}$ and $\mathrm{mg}$

\subsection{2 $\mathrm{K}_{2} \mathrm{O}$ released (in \% $\mathrm{K}_{2} \mathrm{O}$ )}

The cumulative amount of $\mathrm{K}^{+}$released by the aggregate in the $\mathrm{NaOH}$ test solution at the time of the $n$th sampling, in $\%$ of $\mathrm{K}_{2} \mathrm{O}$, is obtained using the following relationship:

$\%_{\text {released }}^{\mathrm{K}_{2} \mathrm{O}}=\left[\mathrm{M}_{\text {released }}^{\mathrm{K}_{2} \mathrm{O}} / \mathrm{kg}\right] / 10^{6} \times 100$

where $10^{6}$, conversion factor between $\mathrm{kg}$ and $\mathrm{mg}$

\subsection{3 $\mathrm{Na}_{2} \mathrm{Oeq}$ released (in $\% \mathrm{Na}_{2} \mathrm{Oeq}$ )}

The cumulative amount of alkalis released by the aggregate in the $\mathrm{NaOH}$ and $\mathrm{KOH}$ test solutions at the time of the $\mathrm{n}^{\text {th }}$ sampling, in $\%$ of $\mathrm{Na}_{2} \mathrm{O}_{\text {eq }}$, is obtained using the following relationship:

$$
\begin{aligned}
\%_{\text {released }}^{\mathrm{Na}_{2} \mathrm{O}_{e q}}= & \%_{\text {released }}^{\mathrm{Na}_{2} \mathrm{O}}(\mathrm{Eq} .7) \\
& +\left[0.658 \times \%_{\text {released }}^{\mathrm{K}_{2} \mathrm{O}}(E q .8)\right]
\end{aligned}
$$

where 0.658 ,conversion factor to transform a mass of $\mathrm{K}_{2} \mathrm{O}$ to the equivalent atomic mass of $\mathrm{Na}_{2} \mathrm{O}$

\subsection{Potential amounts of alkalis releasable} by the aggregate in concrete (in $\mathrm{kg}$ of $\mathrm{Na}_{2} \mathrm{O}_{\mathrm{eq}}$ l $\mathrm{m}^{3}$ )

As mentioned in Sect. 3, the values obtained by this test method present most likely a significant overestimation compared to the release in field concrete. At this stage, it is only possible to categorize the aggregate according to the amount of alkali release. Low releasers are aggregates that are very unlikely to release less than $0.1 \% \mathrm{Na}_{2} \mathrm{Oeq}$ at 26 weeks (corresponding to $1.75 \mathrm{~kg} \mathrm{Na} 2 \mathrm{Oeq} / \mathrm{m}^{3}$ ) while high releasers are aggregates that are very likely to release more than $0.25 \% \mathrm{Na}_{2} \mathrm{Oeq}$ at 26 weeks (corresponding to $4.38 \mathrm{~kg}$ $\mathrm{Na}_{2} \mathrm{O}_{\mathrm{eq}} / \mathrm{m}^{3}$ ). For high releasers, extra caution should be taken in the selection of AAR mitigation measures.

\subsubsection{Field applications}

The potential amount of alkalis releasable by the aggregate under study in concrete, in $\mathrm{kg}$ of $\mathrm{Na}_{2} \mathrm{O}_{\text {eq }}$ per cubic meter of concrete, is obtained using the following relationship:

$$
M_{\text {released }}^{\mathrm{Na}_{2} \mathrm{O}_{e q}} / m^{3}=M_{\text {released }}^{\mathrm{Na}_{2} \mathrm{O}_{e q}} / \mathrm{kg}(\text { see } 8.3 .3) \times M_{e} / 10^{6}
$$

where $M_{e}$, dosage of aggregate in concrete, in $\mathrm{kg} /$ $\mathrm{m}^{3} \cdot 10^{6}$, conversion factor between $\mathrm{kg}$ and $\mathrm{mg}$

\subsubsection{General use}

The potential amount of alkalis releasable by the aggregate, in $\mathrm{kg}$ of $\mathrm{Na}_{2} \mathrm{O}_{\text {eq }}$ per cubic meter of concrete, is obtained using the relationships indicated in 8.5.1,

where

$M_{e}$, average dosage of aggregate in concrete, in $\mathrm{kg} /$ $\mathrm{m}^{3}=1050 \mathrm{~kg} / \mathrm{m}^{3}$ for a coarse aggregate, $700 \mathrm{~kg} / \mathrm{m}^{3}$ for a fine aggregate

$10^{6}$, conversion factor between $\mathrm{kg}$ and $\mathrm{mg}$ 


\section{Test report}

The following information shall be given in the report:

- Aggregate sample (identification, source, chemical composition ( $\mathrm{Na}$ and $\mathrm{K}$ oxides), petrographic description (if available), date of and condition at delivery at the laboratory, grading as received, etc.).

- Processing undertaken on the aggregate sample in the laboratory (washing, drying, sieving etc.).

- Grading of the aggregate as used in the test.

- Characteristics of the test containers used (brand, model, composition, capacity, dimensions, type of lid, etc.).

- Storage conditions (convection oven or water bath, and characteristics).

- Mass of the aggregates tested.

- Analytical method used for chemical analyses.

- $\mathrm{Na}^{+}$concentration in the blank $0.7 \mathrm{M} \mathrm{KOH}$ solution and $\mathrm{K}^{+}$concentration in the blank $0.7 \mathrm{M} \mathrm{NaOH}$ solution, in $\mathrm{mg} / \mathrm{L}$.

- A table giving for each sample, numbered from 1 to $\mathrm{n}$ :

(1) The corresponding sampling time (i.e. 0 (blank solutions), 2, 6, 13, 26 weeks, ...);

(2) The $\mathrm{Na}^{+}$concentration in the $\mathrm{KOH}$ blank solution, in $\mathrm{mg} / \mathrm{L}$;

(3) The $\mathrm{K}^{+}$concentration in the $\mathrm{NaOH}$ blank solution, in $\mathrm{mg} / \mathrm{L}$;

(4) The cumulative mass of $\mathrm{Na}^{+}$released in the $\mathrm{KOH}$ test solution, in $\mathrm{mg}$;

(5) The cumulative mass of $\mathrm{K}^{+}$released in the $\mathrm{NaOH}$ test solution, in $\mathrm{mg}$;

(6) The cumulative amount of $\mathrm{Na}_{2} \mathrm{O}$ released by the aggregate in the $\mathrm{KOH}$ test solution, expressed in $\mathrm{mg} \mathrm{Na} \mathrm{Na}_{2} \mathrm{O} / \mathrm{kg}$ of aggregate;

(7) The cumulative amount of $\mathrm{K}_{2} \mathrm{O}$ released by the aggregate in the $\mathrm{NaOH}$ test solution expressed in $\mathrm{mg} \mathrm{K}_{2} \mathrm{O} / \mathrm{kg}$ of aggregate;

(8) the cumulative amount of $\mathrm{Na}_{2} \mathrm{O}_{\text {eq }}$ released by the aggregates in both test solutions, in $\mathrm{mg}$ $\mathrm{Na}_{2} \mathrm{O}_{\mathrm{eq}} / \mathrm{kg}$ of aggregate;

(9) The cumulative amount of $\mathrm{Na}_{2} \mathrm{O}$ released by the aggregates in $\mathrm{KOH}$ test solution expressed in $\% \mathrm{Na}_{2} \mathrm{O}$;
(10) The cumulative amount of $\mathrm{K}_{2} \mathrm{O}$ released by the aggregates in $\mathrm{NaOH}$ test solution expressed in $\% \mathrm{~K}_{2} \mathrm{O}$;

(11) The cumulative amount of $\mathrm{Na}_{2} \mathrm{O}_{\text {eq }}$ released by the aggregates in both test solutions expressed in $\% \mathrm{Na}_{2} \mathrm{O}_{\text {eq }}$;

(12) The potential amounts of alkalis releasable by the aggregate in concrete, in $\mathrm{kg} \mathrm{Na} \mathrm{Na}_{2} \mathrm{O}_{\mathrm{eq}} / \mathrm{m}^{3}$ based on aggregate contents of $1050 \mathrm{~kg} / \mathrm{m}^{3}$ for a coarse aggregate and $700 \mathrm{~kg} / \mathrm{m}^{3}$ for a fine aggregate.

- A combined graph of the cumulative masses of $\mathrm{Na}_{2} \mathrm{O}, \mathrm{K}_{2} \mathrm{O}$ and $\mathrm{Na}_{2} \mathrm{O}_{\text {eq }}$ released, in $\mathrm{mg} / \mathrm{kg}$ of aggregate and in \% vs. time, all values being " 0 " at the beginning of the test

- Any significant features revealed by examination of the specimens and the alkaline solutions during the test (particle disaggregation, secondary products, color of the solution, etc.)

\section{Declaration}

Conflict of interest The authors declare that they have no conflict of interest.

\section{References}

1. Stark D, Morgan B, Okamoto P, Diamond S (1993) Eliminating or Minimizing Alkali-Silica Reactivity. Report SHRP-C-343. US National Research Council, Washington

2. LCPC Méthode d'essai 37 (1993) Essai de granulat Détermination des alcalins solubles dans l'eau de chaux. Paris, France

3. XP P18-544 (2015) Granulats - Déterminer des alcalins actifs solubles dans l'eau de chaux. France

4. Berube MA, Duchesne J, Rivest M (1996) Alkali Contribution by Aggregates to Concrete. In: Proc 10th ICAAR, Melbourne, Australia: 899-906.

5. Berube MA, Duchesne J, Dorion JF, Rivest M (2002) Laboratory assessment of alkali contribution by aggregates to concrete and application to concrete structures affected by ASR. Cem Concr Res 32(8):1215-1227

6. Berube MA, Fournier B (2002) Alkalis Releasable by Aggregates in Concrete: Significance and Methods. Report RILEM/TC-ARP/02/12 Reykjavik, Iceland

7. Berube MA, Fournier B (2004) Alkalis releasable by aggregates in concrete- significance and tests methods. Proc 12th ICAAR. Beijing, China, pp 17-30

8. Menéndez E, Prendes N, Márquez C, Aldea B (2012) Evaluation of granitic aggregate behaviour in relation with 
the alkaline extraction and compositional change in their phases. In: Proc 14th ICAAR, Austin, USA: Paper 052011.

9. Menéndez E (2013) Extraction of alkalis from aggregates. In: Workshop RILEM/TC-ACS-219, Lisbon, Portugal

10. Soares D, Santos Silva A, Mirão J, Ramos V, Fernandes I, Menéndez E (2015) Assessment of alkalis released by aggregates. Contribution to the alkalinity increase and AAR development in concrete. In: Second International Dam World Conference, Lisbon

11. Menéndez E, García-Roves R, Rúiz S (2016) Alkali release from aggregates: contribution to ASR. Construc Mater 169(4):206-214. https://doi.org/10.1680/jcoma.15.00072

12. Santos Silva A, Fernandes I, Ferraz ARE, Soares D (2017) Can certain alkali minerals explain the slow reactivity of granitic aggregates in dams? In: Swelling Concrete in Dams and hydraulic Structures, ISTE: 93-105. http://10.6.20.12: 80/handle/123456789/9692

13. Menéndez E, García-Roves R, Aldea B, Ruiz S (2016) Alkali release of aggregates effectiveness of different solutions and condition of testing. In: Proc 15th ICAAR, $\mathrm{SaO}$ Paulo, Brazil

14. De Weerdt K, Geiker M, Plusquellec G, Lingard J, Duchesne J, Fournier B (2019) Strategies for quantification of alkali metal release from aggregates in concrete. In: Proc SMSS. Roving, Croatia

15. Drolet C, Duchesne J, Fournier B (2017) Validation of the alkali contribution by aggregates to the concrete pore solution. Cem Concr Res 98:10-23. https://doi.org/10.1016/ j.cemconres.2017.04.001

16. ISO 6274 (1982) Concrete - Sieve analysis of aggregates. Switzerland
17. Diamond S, Penko M (1992) Alkali silica reaction processes: the conversion of cement alkalis to alkali hydroxide. In: Durability of Concrete ACI SP-131, Detroit, USA:153168.

18. Nixon PJ, Page CL (1987) Pore solution chemistry and alkali aggregate reaction. Concrete Durability. In: Proc. Katherine and Bryant Mather International Conference ACI SP-100 (2), Detroit, USA:1833-1862

19. Nixon PJ, Sims I (2016) RILEM Recommended Test Method: AAR-1.1-Detection of Potential Alkali-Reactivity-Part 1: Petrographic Examination Method. In: Nixon P., Sims I. (eds) RILEM Recommendations for the Prevention of Damage by Alkali-Aggregate Reactions in New Concrete Structures. RILEM State-of-the-Art Reports (17):35-60.

20. Nixon PJ, Sims I (2016): RILEM Recommended Test Method: AAR-2 - Detection of Potential Alkali-Reactivity-Accelerated Mortar-Bar Test Method for Aggregates. In: Nixon P., Sims I. (eds) RILEM Recommendations for the Prevention of Damage by Alkali-Aggregate Reactions in New Concrete Structures. RILEM State-of-the-Art Reports (17):61-77.

21. Duchesne J, Santos Silva A, Menéndez E Chemical analysis of alkalis by different instrumental techniques to determine the extraction of alkalis from aggregates (under preparation).

Publisher's Note Springer Nature remains neutral with regard to jurisdictional claims in published maps and institutional affiliations. 